\title{
Review Article \\ From Garbage to Biomaterials: An Overview on Egg Shell Based Hydroxyapatite
}

\author{
Idris Abdulrahman, ${ }^{1}$ Hamzat Ibiyeye Tijani, ${ }^{2}$ Bashir Abubakar Mohammed, ${ }^{3}$ \\ Haruna Saidu, ${ }^{4}$ Hindatu Yusuf, ${ }^{5}$ Mohammed Ndejiko Jibrin, ${ }^{6}$ and Sulaiman Mohammed ${ }^{4}$ \\ ${ }^{1}$ Department of Microbiology, Kaduna State University, P.M.B. 2339, Kaduna, Nigeria \\ ${ }^{2}$ Faculty of Bioscience \& Medical Engineering, Universiti Teknologi Malaysia, 81310 Skudai, Johor Bahru, Malaysia \\ ${ }^{3}$ Department of Biological Sciences, Bauchi State University Gadau, P.M.B. 065, Bauchi, Nigeria \\ ${ }^{4}$ Department of Biological Sciences, Gombe State University, P.M.B. 0127, Gombe, Nigeria \\ ${ }^{5}$ Department of Biochemistry, Bauchi State University Gadau, P.M.B. 065, Bauchi, Nigeria \\ ${ }^{6}$ Department of Microbiology, Ibrahim Badamasi Babangida University Lapai, P.M.B. 011, Niger, Nigeria
}

Correspondence should be addressed to Idris Abdulrahman; idrisaa@live.com

Received 26 March 2014; Revised 14 July 2014; Accepted 14 July 2014; Published 25 August 2014

Academic Editor: Roger Narayan

Copyright (C) 2014 Idris Abdulrahman et al. This is an open access article distributed under the Creative Commons Attribution License, which permits unrestricted use, distribution, and reproduction in any medium, provided the original work is properly cited.

\begin{abstract}
The conversion of waste obtained from agricultural processes into biocompatible materials (biomaterials) used in medical surgery is a strategy that will add more value in waste utilization. This strategy has successfully turned the rather untransformed wastes into high value products. Eggshell is an agricultural waste largely considered as useless and is discarded mostly because it contributes to pollution. This waste has potential for producing hydroxyapatite, a major component found in bone and teeth. Hydroxyapatite is an excellent material used in bone repair and tissue regeneration. The use of eggshell to generate hydroxyapatite will reduce the pollution effect of the waste and the subsequent conversion of the waste into a highly valuable product. In this paper, we reviewed the utilization of this agricultural waste (eggshell) in producing hydroxyapatite. The process of transforming eggshell into hydroxyapatite and nanohydroxyapatite is an environmentally friendly process. Eggshell based hydroxyapatite and nanohydroxyapatite stand as good chance of reducing the cost of treatment in bone repair or replacement with little impact on the environment.
\end{abstract}

\section{Introduction}

Agricultural waste is any waste being generated from different farming processes in accumulative concentration. Adequate utilization of agricultural waste reduces environmental problems caused by irresponsible disposal of the waste. The management of agricultural wastes is indispensable and a crucial strategy in global waste management. Waste of any kind in the environment when its concentration is in excess can become a critical factor for humans, animals, and vegetation [1]. The nature, quantity, and type of agricultural waste generated vary from country to country. The search for an effective way to properly manage agricultural waste will help protect the environment and the health quality.
For sustainable development, wastes should be recycled, reused, and channelled towards the production of value added products. This is to protect the environment on one side and on the other side to obtain value added products while establishing a zero waste standard. The utilization of the waste is a priority today in order to achieve sustainable development [2].

One way that adds great value to agricultural waste is its utilization as a biomaterial used in medical surgery and therapeutics. The production of biocompatible material or biomaterial from agrowaste has added a different dimension to the utilization of agricultural waste for value added product. This is possible because some of this waste contains active compounds that have value in medical applications. This is a novel practice that is expected to have value 
in medical sciences. Most researches on agricultural waste focused mainly on its energy potentials or its use as effective chemical feedstock and as renewable raw materials because of its abundance, its cheap availability, and its renewability [36]. This conversion into valuable products or energy sources is carried out by microorganisms or their components [7]. Many agricultural wastes were reported to be effective feedstock in making useful products [8-10]. The waste is readily available and cheap. Agricultural waste has been proven to serve as a good replacement option which can be used as biomaterials in therapies that replaces bone for the growth of osteoblasts [11]. Avian eggshell is an agricultural waste that received attention and has the potential of being used in medical and dental therapy. The use of other wastes as biomaterials has also been reported [2].

The development of biomaterials for bone tissue replacements has increased and attracted a lot of interest due to the rise in the number of patients that requires bone replacements, especially in those suffering from bone cancer, trauma, and ageing. The biomaterials must be biocompatible with sufficient mechanical strength to support the weight of human body before being used as bone implants [12].

This paper will give an insight into utilization of avian eggshell, an agricultural waste, to produce hydroxyapatite. Eggshells remain largely unutilised and untransformed as they are discarded wrongly. These shells are made up of calcium carbonate that can be used to produce hydroxyapatite, the major inorganic part in bones which is used in bone and dental therapy.

\section{Hydroxyapatite: Relevance in Tissue Engineering}

Hydroxyapatite is a calcium phosphate ceramics material that is found to be very crucial as a biomaterial because of its osteophilic nature and its incorporation into bone tissues [13]. The use of calcium phosphate salts to successfully replace and augment bone tissue is known for many years since it was discovered that calcium phosphate plays a major role in the inorganic phase of hard tissues, bones, and teeth which necessitates medical researchers to consider this salt as a way of improving the healing process [14]. Natural bone is made up from inorganic/organic composite mainly nanostructure hydroxyapatite $\left(\mathrm{Ca}_{10}\left(\mathrm{PO}_{4}\right)_{6}(\mathrm{OH})_{2}, \mathrm{HAp}\right)$ and collagen fibers [15]. Hydroxyapatite (HAp) forms the major inorganic portion of bone and teeth tissue and it is a key requirement for developing bone grafts [16]. Hydroxyapatite has a number of applications in tissue engineering and it is both bioactive and biocompatible with similar chemical composition and biological affinity to the mineral part of bone [17]. Bone mineral is a salt where the ratio of calcium to phosphate $(\mathrm{C} / \mathrm{P})$ is 1.5 to 1.7 and the hydroxyapatite $\mathrm{C} / \mathrm{P}$ ratio is generally assumed to be 1.67 which is within the range [14]. HAp has shown excellent biocompatibility with mostly soft tissues in skin, muscle, and teeth gums. This compatibility with biological tissues has made HAp regarded as superior to other artificial materials [18]. This has qualified HAp to be an ideal implant or an implant component material in orthopaedic and dental surgery.

The aim of tissue engineering is to produce substitutes materials in biological systems that may overcome the challenges facing conventional clinical treatments carried out for damaged tissues or organs. Bone tissue engineering relied heavily on the understanding of the structure of the bone, bone mechanics, and tissue formation in order to induce new and functional bone tissues [19]. Bone tissue damage, loss due to disease, and inefficient healing after accident or traumatic injury are addressed by tissue engineering approach. The principal methods in tissue engineering involve growing the relevant cells to form the required tissue/organ in vitro before inserting them into the body. The cells must first attach to scaffold, a three-dimensional (3D) substrate [20]. The scaffold plays a role as the initial extracellular matrix that will be required to support the cells which qualifies it as a key determinant in tissue engineering [21]. A 3D interconnected structure is required to allow cell attachment and differentiation and proliferation and to provide pathways for body fluids in addition to the composition of the material as suggested by various clinical practices and biological studies [17]. HAp scaffolds made by $3 \mathrm{D}$ printing stand as a good replacement for bone and are very suitable [22]. 3D scaffold settings serve as interim substrates for supporting and guiding the formation of various tissues in either in vitro or in vivo tissueregeneration [23]. A number of characteristics are required before biologically compatible scaffold is qualified to be called ideal; the characteristics include supporting cell attachment and growth, easily biodegradable scaffolds, logical cell substrate interactions, few immune responses and inflammation, minimum cytotoxicity, simple material generation, ease of mobility, purification, and processing as well as chemical compatibility with physiological environments and aqueous solutions [24].

Nanotechnology involves the use of nanoparticles that will help in overcoming many challenges and limitations in the use of biomaterials in tissue engineering. Nanoparticles were integrated into nanostructure scaffolds such that bioactive molecules (growth and differentiation factors) are delivered to regulate optimum tissue regeneration and to ensure regulation of cell behaviour [25]. Scaffold performs the function of an interim synthetic extracellular matrix (ECM) which will interact with cells forming new tissue [25]. Nanosized HAP was newly developed and its properties suggested it to be superior in bone tissue engineering. The nanosized particles were reportedly incorporated into poly(llactic acid) porous scaffolds successfully which improved the mechanical properties as well as protein adsorption of the scaffolds (developed a fibrous morphology which increased the protein adsorption threefold over nonfibrous scaffolds) at the same time maintaining suitable microarchitecture and high porosity [26].

\section{Eggshell: Ideal Source for Hydroxyapatite}

A study has suggested that the recycling of chicken eggshells is a way of improving the ecosphere; it reduces the need of 
TABLE 1: Comparison of HAp produced by various sources.

\begin{tabular}{|c|c|c|c|c|}
\hline Parameters & Bovine bone & Fish bones & Eggshell & Natural bone \\
\hline $\mathrm{Ca} / \mathrm{P}$ ratio & $>1.67$ & $\geq 1.67$ & $\geq 1.67$ & 1.67 \\
\hline Particle size & Micro to nanometer range & $\begin{array}{l}\text { In nanometer } \\
\text { range }\end{array}$ & $\geq 50 \mathrm{~nm}$ & Nanocomposite \\
\hline Morphology & $\begin{array}{l}\text { Needle, rod, plate, } \\
\text { spherical, and so forth }\end{array}$ & $\begin{array}{l}\text { Needle, rod, } \\
\text { spherical, and so } \\
\text { forth }\end{array}$ & Needle or rod & Needle or rod \\
\hline Phase composition & $\begin{array}{l}\text { Phase pure and tricalcium } \\
\text { phosphate }\end{array}$ & Phase pure & Phase pure & Composite \\
\hline Thermal stability & $800-1000^{\circ} \mathrm{C}$ & $600-800^{\circ} \mathrm{C}$ & $<800^{\circ} \mathrm{C}$ & $>1200^{\circ} \mathrm{C}$ \\
\hline Trace elements & $\mathrm{Na}^{+}, \mathrm{Mg}^{2+}, \mathrm{K}^{+}, \mathrm{Ti}^{2+}$, etc & $\begin{array}{l}\mathrm{Fe}^{3+}, \mathrm{Cr}^{3+}, \mathrm{Cu}^{2+} \\
\mathrm{K}^{+}, \mathrm{Mg}^{2+} \text {, and so } \\
\text { forth }\end{array}$ & $\begin{array}{c}\mathrm{CO}_{3}^{2-} \text { major } \\
\text { Element } \mathrm{Mg}^{2+}, \mathrm{Na}^{+}\end{array}$ & $\begin{array}{l}\mathrm{Na}^{+}, \mathrm{Mg}^{2+}, \mathrm{K}^{+} \\
\mathrm{Zn}^{2+}, \mathrm{CO}_{3}{ }^{2-}\end{array}$ \\
\hline
\end{tabular}

management of waste and the eggshells can serve as useful raw materials for nanomaterials [28]. Fresh eggshell consists of a typically three-layered structure; the foamy cuticle layer on the outer surface resembles a ceramic; the middle layer is spongy; the inner layer consists of lamellar layers. It represents almost $11 \%$ of the egg total weight [28]. Calcium carbonate (calcite) is the main component in eggshells and is the major inorganic substance found in an egg and it makes up about $94 \%$ of chemical composition of eggshell. This makes it an essential material for hydroxyapatite production [29]. Others are organic matter which makes up 4\%, magnesium carbonate $(1 \%)$, and calcium phosphate $(1 \%)$ as well as insoluble proteins $[29,30]$. The calcite is the most stable form of calcium carbonate; it forms elongated structures called columns, palisades, or crystallite. Calcification of eggshell is regarded as one of the most rapid known processes of biomineralization and the bulk of mineral found within the eggshell is calcite with a needle like hydroxyapatite in small amounts found in the inner cuticle [29]. The large presence of calcite contributed to the better mechanical properties and strength of eggshell based HAp.

Apart from the eggshell, other natural sources of hydroxyapatite have been identified such as the use of natural bones such as bovine bones and fish bones, cuttle fish shells, oyster shells, and corals. These were successfully converted into biomaterials $[28,31]$. Unlike eggshells, the continuous use of these resources may lead to their extinction and in the case of corals, they have a slow growth rate [28]. Eggshell can therefore serve as a good biomaterial source. The HAp synthesized from eggshell has demonstrated superior sinterability when compared with HAp synthesized from other sources in terms of hardness, density, and cell culture. Cytotoxicity test carried out using osteoblast cell culture has established the biocompatibility of eggshell based HAp [32]. It shows that eggshell based HAp favors adhesion of the osteoblast cells and is noncytotoxic. This might be due to the biological nature of $\mathrm{CaCO}_{3}$ that can improve the properties of the HAp [32]. The HAp from eggshells is of good quality because of its resemblance with human hard tissues [33]. The HAp has been reported to have significantly higher bone formation [34]. The HAp is also smaller in size and cellular response to HAp will depend on the particle size and smaller particles will have more advantages over larger particles. The cellular response also depends on morphology, crystallinity, and chemical composition [35]. The calcination temperature for eggshell based HAp varies from $900^{\circ} \mathrm{C}$ and at this temperature all issues related to disease transmission are contained by destroying pathogens that may transfer diseases to patients. All these features contributed to the excellent quality of eggshell based HAp that is much closer to the composition and structure of biological apatite. This is a major requirement considered before a synthetic apatite can be used to repair damage and hard tissues [36]. A good perspective of using eggshell is its nonexpensiveness and it is an environmentally friendly source for HAp preparation [37].

Unlike eggshell based HAp, the characteristics of HAp extracted from natural bones usually rely on the nature and sources of the bones, calcination temperature, and the extraction technique. Any of these conditions might affect the properties, efficiency, phase purity, and size distribution of HAp.

Table 1 (adapted from [33]) has summarised the major differences between different natural bone sources of HAp and eggshell based HAp in terms of $\mathrm{Ca} / \mathrm{P}$ ratio, particle size, morphology, phase composition, thermal stability, and trace elements.

\section{Methods of Hydroxyapatite Production from Eggshell}

There are several methods for the production of eggshell based hydroxyapatite. One of these methods is the hydrothermal method.

Hydrothermal method is the most widely reported method of HAp production from eggshell. It has been proven to be the most convenient method of HAp production [38]. This method of synthesizing HAp from eggshells in a phosphate solution at a high temperature is a novel way for producing useful biomedical materials [30]. In this method, fine hydroxyapatite single crystals are synthesized by a hydrothermal method with $\mathrm{Ca}(\mathrm{OH})_{2}$ and $\mathrm{CaHPO}_{4} \cdot 2 \mathrm{H}_{2} \mathrm{O}$ as starting materials. In order to identify and characterise HAp as the main phase produced, X-ray powder diffraction 


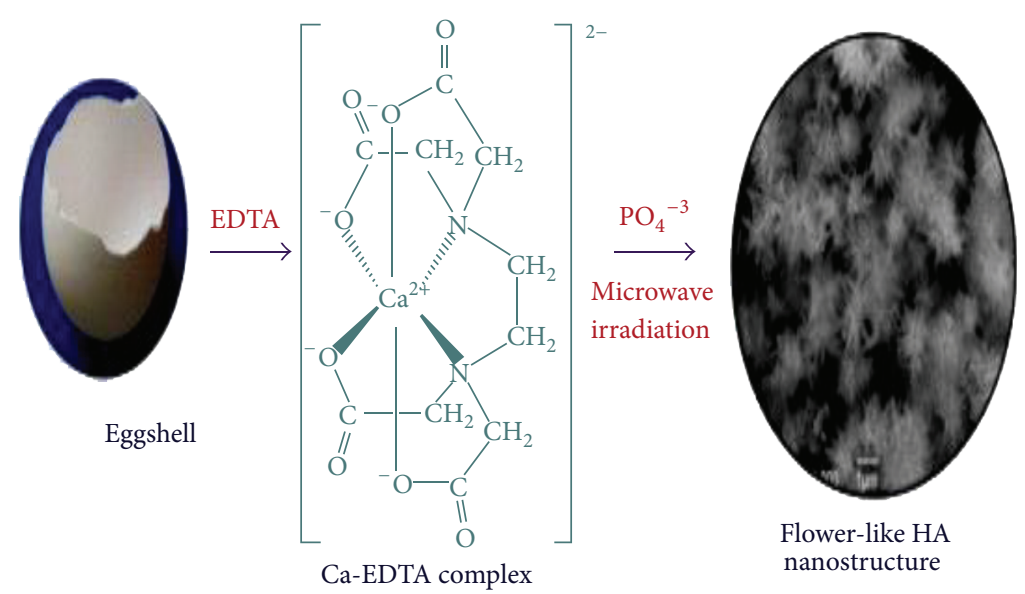

FIGURE 1: Microwave conversion of eggshells into a flower-like hydroxyapatite nanostructure [27].

(XRD) is utilised. The phase identification of the crystals is usually confirmed by Fourier transform infrared spectroscopy (FTIR). Scanning electron microscopy (SEM) and transmission electron microscopy (TEM) are applied to determine particle size and morphology [39]. It can also be characterized by XRD and particle size analysis using laser technique [40]. HAP generated from hydrothermal methods has excellent homogeneity and high crystallinity which is the major advantage of hydrothermal method and the high pressure and temperature used will favour the formation of HAp as the main phase produced [16]. This method is straightforward and direct and it gives all the characteristics band of the HAp but it is time consuming and laborious.

Another method is the use of a simple and rapid microwave irradiation that requires the help of a chelating agent called ethylene diamine tetra acetic acid (EDTA) (Figure 1) [27]. This is an indirect process where the HAp preparation was usually preceded by the preparation of calcium precursor from eggshells as a first step. The structures obtained are required to be subjected to XRD for phase characterisation of the powder obtained. The HAp produced by this method seems to have higher sinterability and stability at high temperatures with better morphology, stoichiometry, and osteoblast cell adhesion. This method has also confirmed the eggshell to be a promising source of calcium for preparing nanocrystalline hydroxyapatite required in bone formation. The X-ray diffraction peaks produced by this method indicate the formation of phase pure HAp [27].

Another method also used in the synthesis of HAp is the high energy mechanochemical activation. This method has been reported to involve the use of the following two mechanochemical activation processes: attrition milling and ball milling [34]. The mechanochemical reaction supplies enough amount of hydroxyl group to the starting powders to form a single phase of hydroxyapatite. Yeong et al. [41] reported attaining a single-phase hydroxyapatite of high crystallinity by $>20 \mathrm{~h}$ of mechanical activation. The resulting hydroxyapatite powder exhibits an average particle size of $\sim 25 \mathrm{~nm}$. Also, increasing degree of activation improves the growth of hydroxyapatite crystallites. The phase composition of the powders is studied by XRD and FTIR spectrometer while SEM is used to identify the morphological characteristics of synthesized powders of the calcined eggshell. The compact morphology of the material alongside the grain size of particles results in a homogenous HAp. From the phases of the synthesized material, the material is found to be dependent on mechanochemical activation method and attrition milling [34]. This suggests that nanocrystallites of hydroxyapatite phase have been formed as a result of mechanical activation. The method is relatively simple, with less cost, and it has been recommended for the mass production of high crystalline hydroxyapatite [42].

The HAp produced by any of these methods will have an excellent biocompatibility and mechanical strength that will allow it to function effectively in tissue repair and regeneration. The HAp demonstrated good ratios with physical shapes similar to crystalline HAp structures found in natural human bone. Eggshell based HAp powders contain many relevant trace elements such as sodium and magnesium [31, 34, 43].

Nanohydroxyapatite can be produced from egg shell using a simple sol-gel precipitation technique. The nanopowders obtained are usually characterized using XRD, TEM, FTIR, and particle size distribution analyzer technique. The result of the powder particles is expectedly polycrystalline in nature with an average size of 5-90 nm. The nano-HAp obtained from this method are of high purity [31]. Nanosized HAp has much higher bioactivity than HAp coarser crystals [28].

\section{Conclusion}

Agricultural waste utilization has made contributions in many aspects of life from its use as feedstock in the production of biobased products and its subsequent use as source of renewable energy. Its utilization has the potential of reducing pollution level and environmental effect exerts by dependence on chemical products. Its use as a biomaterial in biomedical applications has added more value to its utilization. Eggshell produced by chickens and other avians 
is considered as useless mostly but consequently it has value in biomedical applications. Eggshell is considered to be a rich source for calcium as carbonates and oxides that qualify them as excellent sources of hydroxyapatite. Although eggshells are not the first natural source for the synthesis of hydroxyapatite, it provides a cost effective and a renewable as well as a sustainable source of biological HAp. Both hydroxyapatite and nanohydroxyapatite are produced from eggshells. These products were proven by chemical analysis to perform a similar function with hydroxyapatite obtained by other means and they are proven to be biocompatible with mechanical strength and durability to carry out the desired function. With this development, eggshell agricultural waste has made a significant contribution in the production of biomaterials used in medical applications. Its use will help in providing solutions to problems usually encountered as a result of damage and injuries associated with bones and teeth which reduced medical cost and lessened environmental impact.

\section{Conflict of Interests}

The authors declare that there is no conflict of interests regarding the publication of this paper.

\section{References}

[1] T. A. Seadi and J. B. Holm-Nielsen, "Agricultural wastes," in Waste Management Series, I. Twardowska and J. L. William, Eds., Elsevier, 2004.

[2] M. Martin-Luengo, M. Yates, M. Ramos et al., "Renewable raw materials for advanced applications," in Proceedings of the World Congress on Sustainable Technologies (WCST '11), pp. 19-22, IEEE, 2011.

[3] I. H. Ling and D. C. L. Teo, "Lightweight concrete bricks produced from industrial and agricultural solid waste," in Proceedings of the World Congress on Sustainable Technologies (WCST '11), pp. 148-152, November 2011.

[4] S. N. Surip, N. N. Bonnia, H. Anuar, N. A. Hassan, and N. M. Yusof, "Nanofibers from oil palm trunk (OPT): preparation \& chemical analysis," in Proceedings of the IEEE Symposium on Business, Engineering and Industrial Applications (ISBELA '12), pp. 809-812, Bandung, Indonesia, September 2012.

[5] Z. Zakaria, S. Buniran, and M. I. Ishak, "Nanopores activated carbon rice husk," in Proceedings of the International Conference on Enabling Science and Nanotechnology (ESciNano '10), pp. 1-2, Kuala Lumpur, Malaysia, December 2010.

[6] G. Y. Peng, Y. S. Fang, Z. J. Zhe, W. Z. Chen, and Z. M. Yu, "Preparation of active carbon with high specific surface srea from rice husks," Chemical Research in Chinese Universities, vol. 3,2000 .

[7] D. di Gioia, F. Fava, F. Luziatelli, and M. Ruzzi, "6.50-vanillin production from agro-industrial wastes," in Comprehensive Biotechnology, M.-Y. Murray, Ed., Academic Press, Burlington, Vt, USA, 2nd edition, 2011.

[8] Z. Xu, Y. Zhu, M. Liang, H. Zhang, and H. Liu, "Optimization of the preparation conditions for activated carbons from sugarcane bagasse-an agricultural waste," in Proceedings of the International Conference on Computer Distributed Control and
Intelligent Environmental Monitoring (CDCIEM '11), pp. 555559, IEEE, February 2011.

[9] A. Boonpoke, S. Chiarakorn, N. Laosiripojana, S. Towprayoon, and A. Chidthaisong, "Synthesis of activated carbon and MCM41 from bagasse and rice husk and their carbon dioxide adsorption capacity," Journal of Sustainable Energy \& Environment, vol. 2, pp. 77-81, 2013.

[10] N. A. Rashidi, S. Yusup, M. M. Ahmad, N. M. Mohamed, and B. H. Hameed, "Activated carbon from the renewable agricultural residues using single step physical activation: a preliminary analysis," APCBEE Procedia, vol. 3, pp. 84-92, 2012.

[11] M. A. Martin-Luengo, M. Yates, M. Ramos et al., "Biomaterials from beer manufacture waste for bone growth scaffolds," Green Chemistry Letters and Reviews, vol. 4, no. 3, pp. 229-233, 2011.

[12] K. Li and S. C. Tjong, "Preparation and characterization of isotactic polypropylene reinforced with hydroxyapatite nanorods," Journal of Macromolecular Science B: Physics, vol. 50, no. 10, pp. 1983-1995, 2011.

[13] P. Ducheyne, W. van Raemdonck, J. C. Heughebaert, and M. Heughebaert, "Structural analysis of hydroxyapatite coatings on titanium," Biomaterials, vol. 7, no. 2, pp. 97-103, 1986.

[14] K. de Groot, "Clinical applications of calcium phosphate biomaterials: a review," Ceramics International, vol. 19, no. 5, pp. 363-366, 1993.

[15] S. Mulijani and G. Sulistyso, "Formation and characterization of hydroxyapatite/chitosan composite: effect of composite hydroxyapatite coating and its application on biomedical materials," in Chemistry of Phytopotentials: Health, Energy and Environmental Perspectives, L. D. Khemani, M. M. Srivastava, and S. Srivastava, Eds., Springer, Berlin, Germany, 2012.

[16] N. Elizondo-Villarreal, A. Martínez-De-La-Cruz, R. O. Guerra, J. L. Gómez-Ortega, L. M. Torres-Martínez, and V. M. Castaño, "Biomaterials from agricultural waste: eggshell-based hydroxyapatite," Water, Air, and Soil Pollution, vol. 223, no. 7, pp. 36433646, 2012.

[17] H. Ghomi, M. H. Fathi, and H. Edris, "Preparation of nanostructure hydroxyapatite scaffold for tissue engineering applications," Journal of Sol-Gel Science and Technology, vol. 58, no. 3, pp. 642-650, 2011.

[18] H. S. Liu, T. S. Chin, L. S. Lai et al., "Hydroxyapatite synthesized by a simplified hydrothermal method," Ceramics International, vol. 23, no. 1, pp. 19-25, 1997.

[19] A. R. Amini, C. T. Laurencin, and S. P. Nukavarapu, "Bone tissue engineering: recent advances and challenges," Critical Reviews in Biomedical Engineering, vol. 40, no. 5, pp. 363-408, 2012.

[20] S. Dey, "Evaluation of collagen-hydroxyapatite scaffold for bone tissue engineering," in Proceedings of the 13th International Conference on Biomedical Engineering, pp. 1267-1270, Springer, 2009.

[21] R. Lanza, R. Langer, and J. P. Vacanti, Principles of Tissue Engineering, Academic Press, 2011.

[22] B. Leukers, H. Gülkan, S. H. Irsen et al., "Hydroxyapatite scaffolds for bone tissue engineering made by $3 \mathrm{D}$ printing," Journal of Materials Science: Materials in Medicine, vol. 16, no. 12, pp. 1121-1124, 2005.

[23] Y. Luo, G. Engelmayr, D. T. Auguste et al., "Three-dimensional scaffolds," in Principles of Tissue Engineering, R. Lanza, R. Langer, and J. Vacanti, Eds., chapter 25, Academic Press, Burlington, Mass, USA, 3rd edition, 2007.

[24] H. Zhou and J. Lee, "Nanoscale hydroxyapatite particles for bone tissue engineering," Acta Biomaterialia, vol. 7, no. 7, pp. 2769-2781, 2011. 
[25] I. O. Smith, X. H. Liu, L. A. Smith, and P. X. Ma, "Nanostructured polymer scaffolds for tissue engineering and regenerative medicine," Wiley Interdisciplinary Reviews: Nanomedicine and Nanobiotechnology, vol. 1, no. 2, pp. 226-236, 2009.

[26] G. Wei and P. X. Ma, "Structure and properties of nanohydroxyapatite/polymer composite scaffolds for bone tissue engineering," Biomaterials, vol. 25, no. 19, pp. 4749-4757, 2004.

[27] G. S. Kumar, A. Thamizhavel, and E. K. Girija, "Microwave conversion of eggshells into flower-like hydroxyapatite nanostructure for biomedical applications," Materials Letters, vol. 76, pp. 198-200, 2012.

[28] S. Wu, H. Tsou, H. Hsu, S. Hsu, S. Liou, and W. Ho, "A hydrothermal synthesis of eggshell and fruit waste extract to produce nanosized hydroxyapatite," Ceramics International, vol. 39, no. 7, pp. 8183-8188, 2013.

[29] E. C. Li-Chan and H.-O. Kim, "Structure and chemical composition of eggs," Egg Bioscience and Biotechnology, 2008.

[30] E. M. Rivera, M. Araiza, W. Brostow et al., "Synthesis of hydroxyapatite from eggshells," Materials Letters, vol. 41, no. 3, pp. 128-134, 1999.

[31] K. P. Sanosh, M.-C. Chu, A. Balakrishnan, T. N. Kim, and S.-J. Cho, "Utilization of biowaste eggshells to synthesize nanocrystalline hydroxyapatite powders," Materials Letters, vol. 63, no. 24-25, pp. 2100-2102, 2009.

[32] D. Siva Rama Krishna, A. Siddharthan, S. K. Seshadri, and T. S. Sampath Kumar, "A novel route for synthesis of nanocrystalline hydroxyapatite from eggshell waste," Journal of Materials Science: Materials in Medicine, vol. 18, no. 9, pp. 1735-1743, 2007.

[33] M. Akram, R. Ahmed, I. Shakir, W. A. W. Ibrahim, and R. Hussain, "Extracting hydroxyapatite and its precursors from natural resources," Journal of Materials Science, vol. 49, no. 4, pp. 1461-1475, 2014.

[34] G. Gergely, f. Wéber, I. Lukács, and et al, "Preparation and characterization of hydroxyapatite from eggshell," Ceramics International, vol. 36, pp. 803-806.

[35] S. Kim, M. Sun Park, O. Jeon, C. Yong Choi, and B. Kim, "Poly(lactide-co-glycolide)/hydroxyapatite composite scaffolds for bone tissue engineering," Biomaterials, vol. 27, no. 8, pp. 1399-1409, 2006.

[36] Y. Han, K. Xu, G. Montay, T. Fu, and J. Lu, "Evaluation of nanostructured carbonated hydroxyapatite coatings formed by a hybrid process of plasma spraying and hydrothermal synthesis," Journal of Biomedical Materials Research, vol. 60, no. 4, pp. 511-516, 2002.

[37] K. Balázsi, H.-Y. Sim, J.-Y. Choi, S.-G. Kim, C.-H. Chae, and C. Balázsi, "Biogenic nanosized hydroxyapatite for tissue engineering applications," in International Symposium on Biomedical Engineering and Medical Physics, 10-12 October, 2012, Riga, Latvia, vol. 38 of IFMBE Proceedings, pp. 190-193, 2013.

[38] C. Zhang, J. Yang, Z. Quan et al., "Hydroxyapatite nanoand microcrystals with multiform morphologies: controllable synthesis and luminescence properties," Crystal Growth and Design, vol. 9, no. 6, pp. 2725-2733, 2009.

[39] J. Liu, X. Ye, H. Wang, M. Zhu, B. Wang, and H. Yan, "The influence of $\mathrm{pH}$ and temperature on the morphology of hydroxyapatite synthesized by hydrothermal method," Ceramics International, vol. 29, no. 6, pp. 629-633, 2003.

[40] P. Dasgupta, A. Singh, S. Adak, and K. M. Purohit, "Synthesis and characterization of hydroxyapatite produced from eggshell," in Proceedings of the International Symposium of Research Students on Materials Science and Engineering, pp. 1-6, 2004.
[41] K. C. B. Yeong, J. Wang, and S. C. Ng, "Mechanochemical synthesis of nanocrystalline hydroxyapatite from $\mathrm{CaO}$ and $\mathrm{CaHPO}_{4}$," Biomaterials, vol. 22, no. 20, pp. 2705-2712, 2001.

[42] S. Rhee, "Synthesis of hydroxyapatite via mechanochemical treatment," Biomaterials, vol. 23, no. 4, pp. 1147-1152, 2002.

[43] C. Balázsi, P. Gouma, C.-H. Chae, and S.-G. Kim, "Nanostructured hydroxyapatite composite for medical applications," in Proceedings of the 5th European Conference of the International Federation for Medical and Biological Engineering, pp. 996-999, Springer, 2012. 

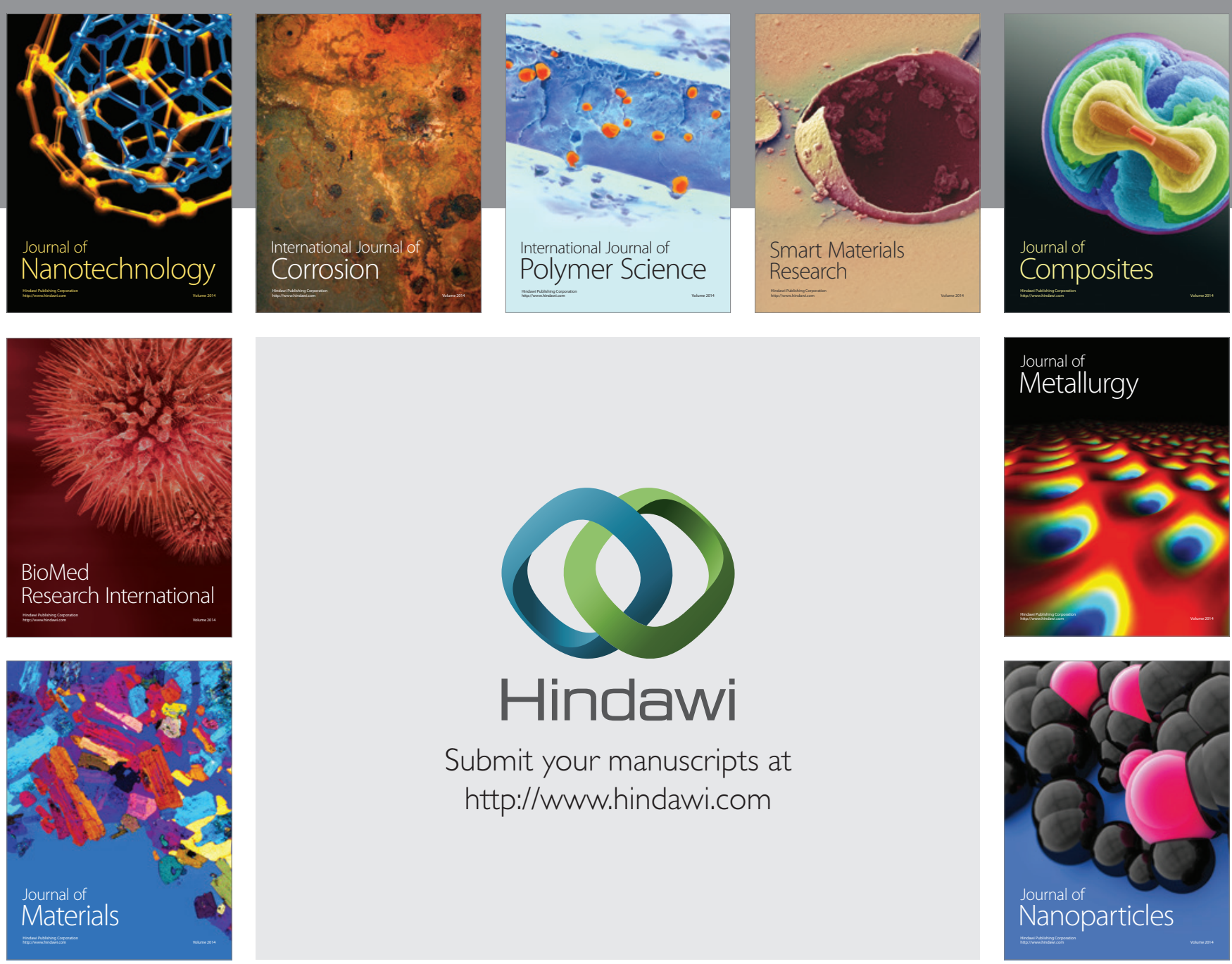

Submit your manuscripts at http://www.hindawi.com
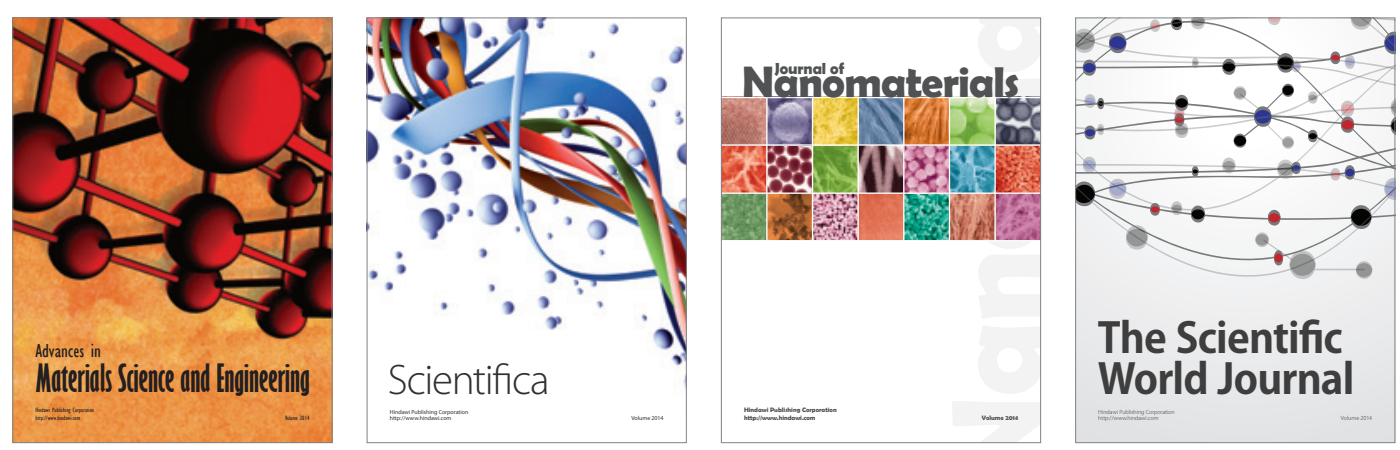

\section{The Scientific World Journal}
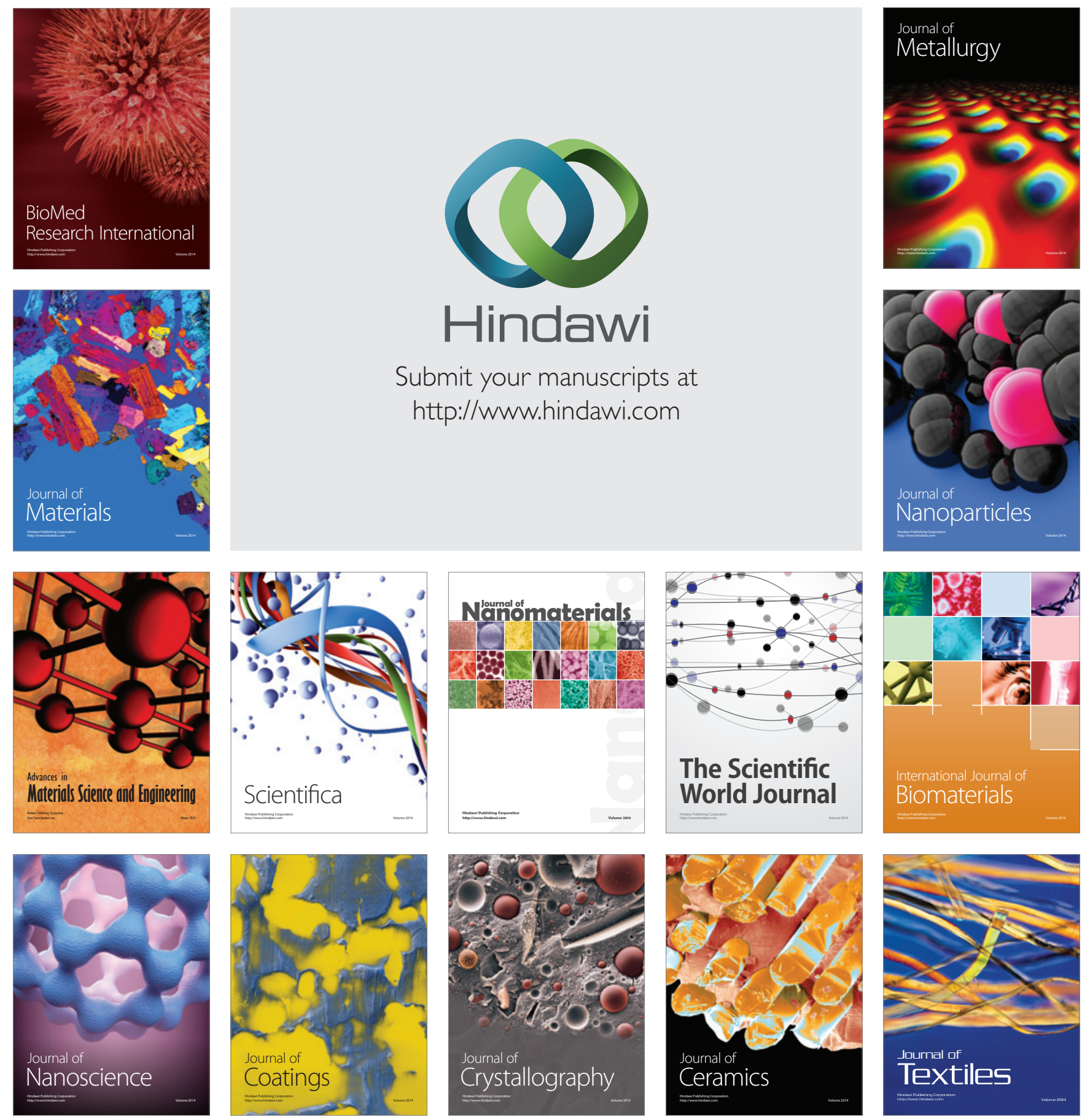